Louisiana State University

LSU Digital Commons

Faculty Publications

Department of Oceanography \& Coastal

Sciences

$11-1987$

\title{
Backfilling Canals to Mitigate Wetland Dredging in Louisiana Coastal Marshes
}

Christopher Neill

R. Eugene Turner

euturne@lsu.edu

Follow this and additional works at: https://digitalcommons.Isu.edu/oceanography_coastal_pubs

\section{Recommended Citation}

Neill, C., \& Turner, R. (1987). Backfilling Canals to Mitigate Wetland Dredging in Louisiana Coastal

Marshes. Environmental Management, 11 (6), 823-836. Retrieved from https://digitalcommons.Isu.edu/

oceanography_coastal_pubs/162

This Article is brought to you for free and open access by the Department of Oceanography \& Coastal Sciences at LSU Digital Commons. It has been accepted for inclusion in Faculty Publications by an authorized administrator of LSU Digital Commons. For more information, please contact ir@lsu.edu. 


\section{Backfilling Canals to Mitigate Wetland Dredging in Louisiana Coastal Marshes}

\author{
CHRISTOPHER NEILL* \\ R. EUGENE TURNER \\ Center for Wetland Resources \\ Department of Marine Sciences \\ Louisiana State University \\ Baton Rouge, Louisiana 70803, USA
}

\begin{abstract}
Returning canal spoil banks into canals, or backfilling, is used in Louisiana marshes to mitigate damage caused by dredging for oil and gas extraction. We evaluated 33 canals backfilled through July 1984 to assess the success of habitat restoration. We determined restoration success by examining canal depth, vegetation recolonization, and regraded spoil bank soils after backfilling. Restoration success depended on: marsh type, canal location, canal age, marsh soil characteristics, the presence or absence of a plug at the canal mouth, whether mitigation was on- or off-site, and dredge operator performance.
\end{abstract}

Backfilling reduced median canal depth from 2.4 to $1.1 \mathrm{~m}$, restored marsh vegetation on the backfilled spoil bank, but did not restore emergent marsh vegetation in the canal because of the lack of sufficient spoil material to fill the canal and time. Median percentage of cover of marsh vegetation on the canal spoil banks was $51.6 \%$. Median percentage of cover in the canal was $0.7 \%$. The organic matter and water content of spoil bank soils were restored to values intermediate between spoil bank levels and predredging marsh conditions.

The average percentage of cover of marsh vegetation on backfilled spoil banks was highest in intermediate marshes $(68.6 \%)$ and lowest in fresh (34.7\%) and salt marshes $(33.9 \%)$. Average canal depth was greatest in intermediate marshes $(1.50 \mathrm{~m})$ and least in fresh marshes $(0.85 \mathrm{~m})$. Canals backfilled in the Chenier Plain of western Louisiana were shallower (average depth $=0.61 \mathrm{~m}$ ) than in the eastern Deltaic Plain (mean depth range $=1.08$ to $1.30 \mathrm{~m}$ ), probably because of differences in sediment type, lower subsidence rate, and lower tidal exchange in the Chenier Plain. Canals backfilled in marshes with more organic soils were deeper, probably as a result of greater loss of spoil volume caused by oxidation of soil organic matter. Canals ten or more years old at the time of backfilling had shallower depths after backfilling. Depths varied widely among canals backfilled within ten years of dredging. Canal size showed no relationship to canal depth or amount of vegetation reestablished. Plugged canals contained more marsh reestablished in the canal and much greater chance of colonization by submerged aquatic vegetation compared with unplugged canals. Dredge operator skill was important in leveling spoil banks to allow vegetation reestablishment. Wide variation in dredge performance led to differing success of vegetation restoration.

Complete reestablishment of the vegetation was not a necessary condition for successful restoration. In addition to providing vegetation reestablishment, backfilling canals resulted in shallow water areas with higher habitat value for benthos, fish, and waterfowl than unfilled canals. Spoil bank removal also may help restore water flow patterns over the marsh surface. Increased backfilling for wetland mitigation and restoration is recommended.
Dredged canals are common features in coastal wetlands. Approximately $8 \%$ of the marshes in coastal Louisiana have been converted to canals and associated spoil banks. These modifications have been linked to several significant wetland impacts including

KEY WORDS: Backfilling; Mitigation; Wetlands; Louisiana; Dredging

\footnotetext{
*Author to whom communications should be addressed. Present address: Department of Forestry and Wildlife Management, University of Massachusetts, Amherst, Massachusetts 01003, USA.
}

direct conversion of marsh to open water or spoil (nonwetland), saltwater intrusion and other deleterious hydrologic changes, and increased wetland to open water habitat changes (Gagliano 1973, Adkins and Bowman 1976, Craig and others 1979, Gagliano and others 1981, Scaife and others 1983, Turner 1985). Because of the widespread distribution and serious impacts of canals, effective management plans to slow or reverse wetland loss must address management of existing and new canals.

The majority of canals in Louisiana wetlands were built by the petroleum industry (Davis 1973). Oil and gas rig access canals are typically $2.4 \mathrm{~m}$ to $3.0 \mathrm{~m}$ deep, 
$20 \mathrm{~m}$ to $40 \mathrm{~m}$ wide, and range in length from approximately $100 \mathrm{~m}$ to $2000 \mathrm{~m}$. The canal terminus is an enlarged turning basin or slip, which gives oil and gas canals a characteristic "keyhole" shape. A typical slip is approximately $50 \mathrm{~m}$ by $100-150 \mathrm{~m}$ (Longley and others 1978). A 365-m-long canal, slip, and spoil bank has a total area of approximately 3.6 ha to 4.5 ha (Longley and others 1978).

Filling canals back in, or backfilling, has been proposed to reduce the harmful effects of canals (Adkins and Bowman 1976, Lindall and others 1979, Turner and others 1983, Bahr and others 1983, Mendelssohn and others 1984). Backfilling has been carried out onsite for canal restoration after well abandonment, and off-site as mitigation for other dredging. Backfilling is performed by a barge-mounted bucket dredge or dragline which uses the previously deposited spoil banks to fill the existing canal, and the spoil banks are regraded to as near to marsh elevation as possible and the fill is placed uniformly over the bottom of the canal (Figure 1).

The intended benefits of backfilling are:

1) Reestablishment of marsh vegetation in the canal and on the regraded spoil bank.

2) Restoration of marsh soils on the regraded spoil bank.

3) Restoration of natural hydrological conditions including reestablishing the original drainage patterns.

4) Restoration of habitat for fish and wildlife.

It is the objective of this article to document the location of all canals in Louisiana that have been restored by backfilling, to describe their characteristics, and to analyze the factors influencing the success or failure of the restoration. Our purpose was to provide information to increase the effectiveness of future restoration and mitigation. We examine backfilling success as influenced by: marsh type, hydrologic unit, time between dredging and backfilling, canal size, soil organic matter content, presence or absence of a plug at the canal mouth, whether mitigation was on- or offsite, and dredge operator skill. We know of no previous examination of existing backfilled canals or review of the effectiveness of backfilling. There are few studies that evaluate the effectiveness of wetland mitigation projects anywhere in the US (Quammen 1986).

\section{Materials and Methods}

During 1983 and 1984 we compiled information on all known backfilled canals in Louisiana from the
Before Backfilling

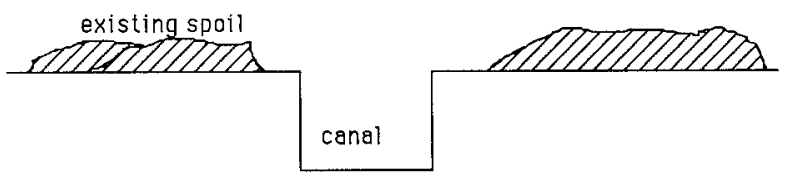

After Backfilling

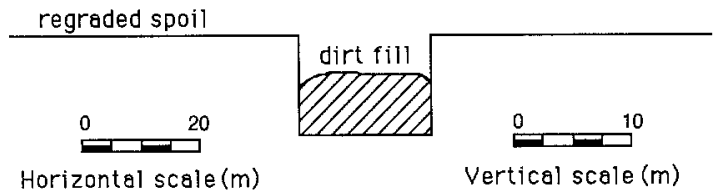

Figure 1. Schematic representation of a typical oil and gas rig access canal before and after backfilling.

Louisiana Department of Natural Resources-Coastal Management Division coastal use permits, oil company records, and on-site visits. Observations and photographs of all canals were made from a small airplane. We used data from permits and oil company records to determine the date of dredging and backfilling, canal length, area of emergent marsh disturbed by the canal, and whether backfilling was performed on-site or off-site. The area of each canal closely resembled the dimensions specified in the permit, but the area of spoil was more variable. The area disturbed by the spoil banks was therefore calculated by multiplying the ratio of spoil-canal area by the canal area. The vegetation-salinity zone was determined by comparing canal location with a vegetation map (Chabreck and Linscombe 1978). Location within hydrologic units based on historic deltaic drainages was determined by comparing each canal location with geologic maps (Wicker and others 1980, Wicker 1981).

We determined the percentage of cover of emergent marsh vegetation reestablished in the backfilled canal and on the regraded spoil bank from $35 \mathrm{~mm}$ slide photographs taken from an altitude of approximately $300 \mathrm{~m}$. Slides were projected and tracings made to measure plant cover. Relative areas of remaining spoil and open water also were measured from the projections.

On the basis of the rates of vegetation reestablishment observed in this study, we concluded that a minimum of six months after backfilling was required to determine if the backfilled canal or spoil bank would be recolonized by marsh. If a canal was backfilled less than six months before we photographed it, no calculations of vegetation cover were made of that canal.

Some differences in vegetation cover between canals may be a result of differences in canal age. However, observations of individual canals during the 
two-year study period and a comparison of adjacent canals of different ages indicate that the area of marsh in the canal or on the regraded spoil banks, once established on sites of suitable elevation, does not change rapidly over the course of two to five years. Rates of change of marsh area at individual canals over time were not estimated.

Canal depths were determined with a recording fathometer operated from a small boat, except in four cases where we measured depth every 3 to $5 \mathrm{~m}$ along transects using a meter stick and at two sites where access was restricted and depth was estimated from a few measurements taken at selected points in the canal. Because water level records were not available for widely scattered locations, we measured elevation relative to mean elevation of adjacent marsh rather than to mean water level. All depths were recorded relative to marsh elevation by measuring the difference in elevation between a point in the adjacent marsh and the water in the canal using a line and a level. Sasser (1977) found that mean marsh elevation was not distinguishable statistically from mean water level for marshes composed of most important Louisiana marsh plant species.

We determined the presence/absence and species of submerged aquatic vegetation from ground observations.

We determined the status of the plug at the mouth of the canal (plugged, unplugged, partially plugged) from the aerial photographs and ground observations.

We estimated the percentage of the spoil bank returned to the canal during backfilling from aerial photographs and ground observations.

We took three replicate soil samples from spoil banks at nonbackfilled canals, regraded spoil banks, and inland marsh $(50 \mathrm{~m}$ inland from the edge of the canal) at each canal using a 50 -cc piston core (Swenson 1983). Water content was determined by drying cores to a constant weight at $85^{\circ} \mathrm{C}$. Organic matter content was measured as the loss on ignition for four hours at $550^{\circ} \mathrm{C}$.

The recovery of organic matter content or water content for a canal was judged to be complete if values for the backfilled spoil bank and adjacent undisturbed marsh were not significantly different $(t$-test, $p<0.05)$. Recovery was judged to be zero if values for the backfilled spoil bank were not significantly different from unfilled spoil. If the values for the backfilled spoil bank were significantly different from both unfilled spoil and undisturbed marsh and lay somewhere between these values, recovery was judged to be partial.

The effects on restoration of marsh type, hydrologic unit, presence of a plug and whether mitigation was on- or off-site were examined by calculating mean values for depth, plant cover, and spoil returned for each marsh type, hydrologic unit, plug and mitigation circumstance. The canals examined were not drawn from an infinite population but instead represented a high proportion of all existing backfilled canals. To take into account sampling a finite population, the standard error of the mean (S.E.) for each category was calculated as:

$$
\text { S.E. }=\sqrt{\frac{s^{2}}{n} \frac{(N-n)}{N}}
$$

where $N=$ the number of all existing backfilled canals $s=$ the sample variance

$n=$ the number of canals sampled (Snedecor and Cochran 1967)

A standard error of zero indicates that all existing canals in that category were sampled and the mean was determined exactly.

\section{Results and Discussion}

\section{Issuance of Permits for Backfilling}

Permits requiring canal backfilling were issued on a case-by-case basis for 33 backfilled canals located throughout the coastal zone (Figure 2). These represented all backfilled canals that could be located through 1984. The first two canals were backfilled in 1979. The number of canals backfilled each year thereafter increased until 1981, when nine canals were filled. Six canals were backfilled in 1983, but only two in 1984.

Permits were issued for backfilling under two circumstances: on-site after abandonment of a canal following a dry hole, or off-site at another canal location if a productive well was struck and the permitted canal was not abandoned. Most canals backfilled on-site were filled within one year of dredging, and never more than three years after dredging (Figure 3). Permittees selected older, existing canals for backfilling off-site. Fourteen of the 16 canals backfilled off-site were filled more than four years after dredging. This difference in issuance of permits for backfilled canals resulted in two groups of backfilled canals differing in age at the time of backfilling. Eleven canals backfilled as on-site mitigation were filled within one year of dredging, and 12 canals filled off-site were filled more than six years after dredging. Eight canals were backfilled between one and six years after dredging. Because of this difference in canal age, and therefore potential differences in spoil bank compaction, it was sus- 


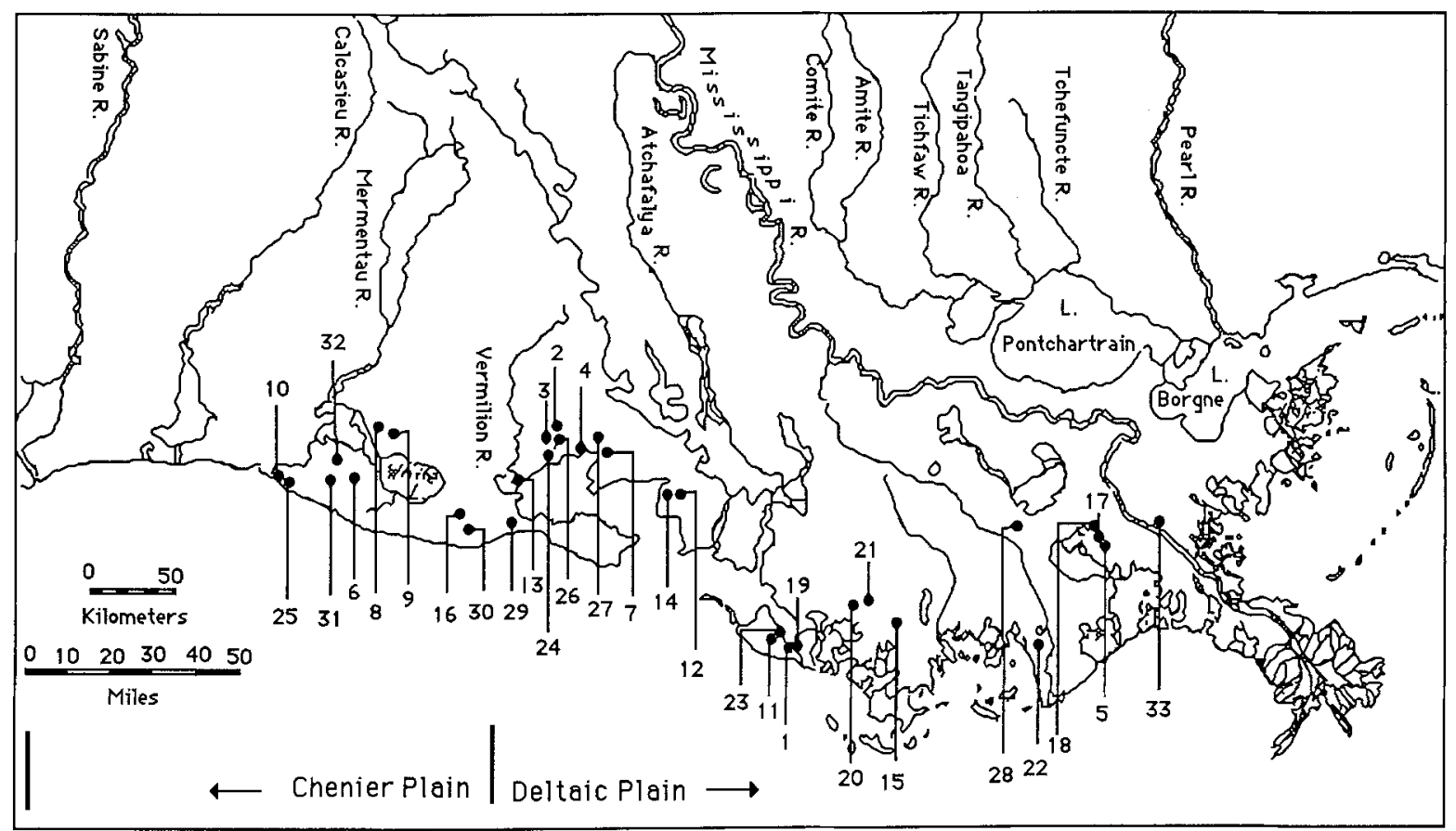

Figure 2. Location of Louisiana backfilled canals.

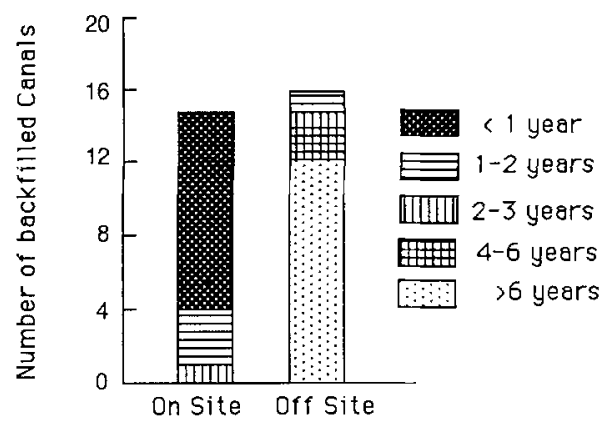

Figure 3. The number of canals backfilled as mitigation onsite or off-site and time between dredging and backfilling.

pected that restoration success might differ depending on whether mitigation was on- or off-site.

The dimensions of backfilled canals varied from small $120-\mathrm{m}$ slips to more than 914-m major oil and gas access canals (Table 1). The longest single backfilled canal was $1432 \mathrm{~m}$. The largest backfilling operation was performed at Pecan Island, in which portions of three canals totaling more than $1859 \mathrm{~m}$ were backfilled. The highest number of backfilled canals (11) fell into the $305-\mathrm{m}$ to $457-\mathrm{m}(1000-1500 \mathrm{ft})$ category. Six canals were $152 \mathrm{~m}(500 \mathrm{ft})$ long, or less, and four canals were longer than $762 \mathrm{~m}(2500 \mathrm{ft})$.

Canal dredging disturbed from 1.7 ha to 11.6 ha of marsh (Table 1). The largest number of canals (16) disturbed between 4 ha and 6 ha of marsh. The total area of canal and spoil was greater than 6 ha at only four sites.

Three canals were backfilled in salt marshes, 17 in brackish, 7 in intermediate, and 6 in fresh marshes (Table 1).

Earthen or shell plugs were constructed at the mouths of 24 backfilled canals. Nine canals had no plugs. Plugs at 10 canals had eroded, allowing limited water exchange.

\section{Success of Restoration}

Characterization of a typical backfilled canal. Backfilled canals varied in size, age, and success of restoration as measured by depth and marsh reestablishment. Ninety-four \% of the available spoil material at a typical canal was backfilled 2.1 years after the canal was originally dredged (Table 2). The median canal depth after backfilling was $1.1 \mathrm{~m}$. The median percentage of cover of the marsh reestablished on the backfilled spoil banks was $51.6 \%$. The median cover of spoil was $22.2 \%$ and open water $21.4 \%$.

Return of spoil banks. Successful restoration of a canal by backfilling requires the effective return of the spoil bank material into the canal. Ninety $\%$ or more of the spoil material was returned at 20 of 31 canals examined (Table 3), and at 15 of these canals $95 \%$ or more of existing spoil was returned. This indicates that present backfilling methods using a bucket dredge can work adequately. In some cases, however, there were 
Table 1. Characteristics of Louisiana backfilled canals.

\begin{tabular}{|c|c|c|c|c|c|c|c|c|}
\hline \multirow[b]{2}{*}{ No. Location name } & \multirow{2}{*}{$\begin{array}{c}\text { Age at } \\
\text { backfilling } \\
\text { (years) }\end{array}$} & \multirow{2}{*}{$\begin{array}{l}\text { Length } \\
\text { (m) }\end{array}$} & \multirow[b]{2}{*}{ Plug } & \multirow{2}{*}{$\begin{array}{l}\text { On- or } \\
\text { off-site }\end{array}$} & \multicolumn{2}{|c|}{$\begin{array}{l}\text { Area disturbed } \\
\text { (ha) }\end{array}$} & \multirow{2}{*}{$\begin{array}{l}\text { Marsh } \\
\text { type }\end{array}$} & \multirow{2}{*}{$\begin{array}{c}\% \text { Soil } \\
\text { organic } \\
\text { matter }\end{array}$} \\
\hline & & & & & Canal & Spoil & & \\
\hline 1. Hellhole Lake & 0.9 & 1432 & Yes & On-site & 3.4 & 7.2 & Salt & 4.6 \\
\hline 2. Boston Bayou North & 19.3 & 243 & No & Off-site & 1.3 & 3.0 & Brackish & 35.9 \\
\hline 3. Boston Canal & 0.3 & 365 & Yes & On-site & 1.1 & 3.9 & Brackish & 50.7 \\
\hline 4. Tigre Lagoon & 0.3 & 152 & No & On-site & 0.6 & 1.3 & Brackish & 31.2 \\
\hline 5. Golette Bay & 0.5 & 300 & Partial & On-site & 0.9 & 2.2 & Brackish & 64.0 \\
\hline 6. Grand Lac L'Huit & 18.3 & 487 & Yes & Off-site & 1.4 & 2.8 & Fresh & 67.8 \\
\hline 7. Bayou Carlin & 0.2 & 146 & Partial & On-site & 1.5 & 3.3 & Intermediate & nd \\
\hline 8. Mallard Bay West & 0.6 & 354 & Yes & On-site & 1.2 & 2.5 & Fresh & 60.6 \\
\hline 9. Mallard Bay East & 0.2 & 295 & Yes & On-site & 1.0 & 2.3 & Fresh & 50.9 \\
\hline 10. Mermentau River & 5.0 & 229 & Partial & Off-site & 1.3 & 3.2 & Brackish & 11.8 \\
\hline 11. Mosquito Bay & 0.2 & 152 & No & On-site & 0.7 & 1.7 & Brackish & 29.0 \\
\hline 12. Lake Point Bayou & 11.3 & 609 & No & Off-site & 1.6 & 2.7 & Fresh & 53.2 \\
\hline 13. Vermilion River & 1.9 & 670 & Partial & Off-site & 1.7 & 4.5 & Intermediate & 25.0 \\
\hline 14. Bayou Long & 6.3 & 457 & No & Off-site & 1.3 & 3.2 & Intermediate & 52.7 \\
\hline 15. Four Isle Bay & 7.3 & 426 & Partial & Off-site & 1.3 & 3.2 & Salt & 48.4 \\
\hline 16. Pecan Island West & 34.1 & 1859 & Yes & Off-site & 3.6 & 8.0 & Brackish & 31.4 \\
\hline 17. Lafitte & 8.4 & 152 & No & Off-site & 0.7 & 1.0 & Brackish & 53.5 \\
\hline 18. Dupree Cut & 4.3 & 152 & Partial & Off-site & 0.7 & 1.5 & Brackish & nd \\
\hline 19. Buckskin Bayou & 0.2 & 609 & Yes & On-site & 1.4 & 3.2 & Brackish & 23.7 \\
\hline 20. Lake DeCade & 6.8 & 314 & Partial & Off-site & 1.1 & 2.2 & Intermediate & 42.3 \\
\hline 21. Falgout Canal & 8.3 & 400 & Yes & Off-site & 1.2 & 2.6 & Intermediate & 75.6 \\
\hline 22. Catfish Lake & 2.8 & 457 & Partial & Off-site & 1.3 & 2.2 & Brackish & 49.3 \\
\hline 23. Fourleague Bay & 21.9 & 304 & No & Off-site & 1.0 & 1.5 & Brackish & 41.5 \\
\hline 24. Intracoastal at Oaks Canal & 1.5 & 399 & Yes & On-site & 1.3 & 3.0 & Brackish & nd \\
\hline 25. Lower Mud Lake & 0.8 & 120 & Partial & On-site & 1.2 & 3.3 & Salt & 8.2 \\
\hline 26. Boston Bayou South & 18.6 & 609 & No & Off-site & 1.6 & 4.1 & Brackish & 35.9 \\
\hline 27. Iberia Canal & 2.1 & 1219 & Yes & On-site & 2.9 & 8.2 & Intermediate & 77.3 \\
\hline 28. Delta Farms & 1.4 & 434 & Partial & On-site & 1.4 & 2.8 & Fresh & 82.8 \\
\hline 29. Rainey Refuge & 2.0 & 173 & Yes & On-site & 0.7 & 1.4 & Brackish & 17.6 \\
\hline 30. Pecan Island East & 40.1 & 826 & Yes & Off-site & 1.8 & 3.6 & Brackish & 26.9 \\
\hline 31. Superior Bridge & nd & 457 & Yes & nd & 1.3 & 4.6 & Intermediate & 67.8 \\
\hline 32. Long Island & nd & 457 & No & nd & 1.3 & 2.6 & Fresh & 67.8 \\
\hline 33. Point a la Hache & 0 & 664 & Yes & On-site & 1.8 & 4.1 & Brackish & nd \\
\hline
\end{tabular}

nd $=$ no data.

Table 2. Characteristics of a typical backfilled canal.

\begin{tabular}{|c|c|c|c|c|}
\hline Characteristic & Median & Maximum & Minimum & $\mathrm{N}$ \\
\hline Length (m) & 400.0 & 1859.0 & 120.0 & 33 \\
\hline Canal area (ha) & 1.3 & 3.6 & 0.6 & 33 \\
\hline Spoil area (ha) & 3.0 & 8.2 & 1.0 & 33 \\
\hline $\begin{array}{l}\text { Percent spoil } \\
\text { returned }\end{array}$ & 94.0 & 100.0 & 45.0 & 31 \\
\hline $\begin{array}{l}\text { Years between } \\
\text { dredging and } \\
\text { backfilling }\end{array}$ & 2.1 & 40.1 & 0 & 31 \\
\hline Depth $(\mathrm{m})$ & 1.1 & 1.8 & 0.1 & 26 \\
\hline $\begin{array}{l}\text { Percent marsh cover } \\
\text { in canal }\end{array}$ & 0.7 & 40.1 & 0 & 26 \\
\hline $\begin{array}{l}\text { Percent marsh cover } \\
\text { on spoil }\end{array}$ & 51.6 & 98.5 & 0 & 31 \\
\hline $\begin{array}{l}\text { Percent spoil cover } \\
\text { on spoil }\end{array}$ & 22.2 & 92.8 & 0 & 31 \\
\hline $\begin{array}{l}\text { Percent open-water } \\
\text { cover on spoil }\end{array}$ & 21.4 & 100.0 & 0.1 & 31 \\
\hline
\end{tabular}

obvious deficiencies in the amount of spoil returned. In five cases, $70 \%$ or less of the available spoil was returned to the canal; the remainder was left along the canal edges. We believe that the observed variation in the amount of spoil returned was primarily a result of differences in dredge operator skill, time, or effort, not an inherent inadequacy of the technique. Alternative technologies such as a small bulldozer blade mounted on a marsh buggy probably could improve the success of restoration and should be explored.

Depth. Backfilling reduced the depth of canals but has not filled them completely (Table 3 ). Eight canals were filled to $0.5 \mathrm{~m}$ deep or less, 13 to $1 \mathrm{~m}$ or less, and 5 to more than $1.5 \mathrm{~m}$ deep. Two canals had depths of $1.8 \mathrm{~m}$, which was virtually no different than unfilled portions of the same canals.

Marsh vegetation in the canal. Since backfilling did not completely fill most canals, it was not generally ef- 
Table 3. Measures of the success of restoration of backfilled canals.

\begin{tabular}{|c|c|c|c|c|c|c|}
\hline \multirow[b]{3}{*}{ Canal } & \multirow{3}{*}{$\begin{array}{l}\% \text { Spoil } \\
\text { returned } \\
\text { to canal }\end{array}$} & \multirow{3}{*}{$\begin{array}{l}\text { Average } \\
\text { depth } \\
\text { (m) }\end{array}$} & \multicolumn{4}{|c|}{ Percent cover } \\
\hline & & & \multirow[b]{2}{*}{$\begin{array}{l}\text { \% Marsh } \\
\text { in canal }\end{array}$} & \multicolumn{3}{|c|}{ Spoil banks } \\
\hline & & & & $\begin{array}{c}\% \\
\text { Marsh }\end{array}$ & $\begin{array}{c}\% \\
\text { Spoil }\end{array}$ & $\begin{array}{c}\% \\
\text { Open water }\end{array}$ \\
\hline 1. Hellhole Lake & nd & nd & 0 & 4.4 & 78.7 & 16.9 \\
\hline 2. Boston Bayou North & 50 & 1.1 & 0 & 6.4 & 56.6 & 37.0 \\
\hline 3. Boston Canal & 96 & 1.2 & 2.3 & 19.1 & 3.3 & 77.7 \\
\hline 4. Tigre Lagoon & 85 & 1.0 & 3.2 & 54.6 & 35.0 & 10.5 \\
\hline 5. Golette Bay & 99 & 1.1 & 0 & 62.4 & 6.7 & 30.9 \\
\hline 6. Grand Lac L'Huit & 97 & 1.0 & 6.0 & 62.0 & 3.0 & 35.0 \\
\hline 7. Bayou Carlin & 99 & nd & 0 & 90.1 & 6.8 & 3.1 \\
\hline 8. Mallard Bay West & 95 & 0.6 & 12.2 & 19.5 & 22.8 & 57.7 \\
\hline 9. Mallard Bay East & 97 & 0.4 & 26.0 & 22.1 & 10.1 & 67.8 \\
\hline 10. Mermentau River & 82 & 0.4 & 5.8 & 52.1 & 39.3 & 8.6 \\
\hline 11. Mosquito Bay & 94 & 0.4 & 0 & 63.9 & 10.5 & 25.7 \\
\hline 12. Lake Point Bayou & 98 & 1.4 & 1.0 & 43.3 & 6.0 & 50.7 \\
\hline 13. Vermilion River & 82 & 1.0 & 0 & 76.1 & 19.2 & 4.7 \\
\hline 14. Bayou Long & 50 & 1.3 & 1.8 & 51.6 & 48.3 & 0.1 \\
\hline 15. Four Isle Bay & 80 & 1.8 & 0 & 49.0 & 25.6 & 25.4 \\
\hline 16. Pecan Island West & 100 & 0.1 & 40.1 & 77.3 & 0.8 & 21.9 \\
\hline 17. Lafitte & 60 & 1.5 & 0 & 10.5 & 85.4 & 4.1 \\
\hline 18. Dupree Cut & 70 & 0.1 & 10.8 & 6.4 & 92.8 & 0.8 \\
\hline 19. Buckskin Bayou & 98 & 1.5 & 0 & 76.0 & 4.4 & 19.5 \\
\hline 20. Lake DeCade & 78 & 1.8 & 0 & 31.5 & 66.7 & 1.8 \\
\hline 21. Falgout Canal & 93 & 1.6 & 0 & 56.1 & 9.1 & 34.8 \\
\hline 22. Catfish Lake & 90 & 1.5 & 0 & 50.0 & 28.6 & 21.4 \\
\hline 23. Fourleague Bay & 89 & 0.6 & 0 & 48.5 & 43.2 & 8.2 \\
\hline 24. Intracoastal at Oaks & 92 & 0.5 & 14.7 & 68.9 & 20.8 & 10.3 \\
\hline 25. Lower Mud Lake & 96 & 0.2 & 26.7 & 60.2 & 1.8 & 38.0 \\
\hline 26. Boston Bayou South & 45 & 0.5 & 0 & 17.0 & 42.3 & 40.6 \\
\hline 27. Iberia Canal & 98 & 1.7 & 0 & 76.3 & 22.2 & 1.5 \\
\hline 28. Delta Farms & 97 & nd & nd & nd & nd & nd \\
\hline 29. Rainey Refuge & 97 & nd & 3.5 & 56.8 & 22.2 & 21.1 \\
\hline 30. Pecan Island East & 100 & nd & 0 & 0 & 0 & 100.0 \\
\hline 31. Superior Bridge & 99 & 1.6 & 6.6 & 98.5 & 0 & 1.5 \\
\hline 32. Long Island & 90 & nd & 0.7 & 26.6 & 42.6 & 30.9 \\
\hline 33. Pointe a la Hache & nd & nd & nd & nd & nd & nd \\
\hline
\end{tabular}

nd $=$ no data.

fective in reestablishing emergent marsh vegetation in the area formerly covered by the canal. In some cases all available spoil was used as fill, yet no marsh was reestablished in the canals (Figure 4). This occurred because the volume of spoil available for backfilling was less than that of the originally dredged material. Most marsh reestablishment occurred as small clumps of marsh near the canal edges or mouth. Backfilling resulted in the reestablishment of significant amounts (more than 10\% cover) of emergent marsh in a small number of canals. In these cases, where recovery was much better than average, marsh was usually established throughout the canal. In one canal, exceptional recovery resulted in marsh cover of $40 \%$.

Marsh vegetation quickly colonized areas of bare soil created by the backfilling dredge if the resulting soil elevation was both high enough to be within the flooding tolerance of marsh plants and low enough to prevent colonization of spoil vegetation. Most marsh vegetation in coastal Louisiana is found $15 \mathrm{~cm}$ below to $15 \mathrm{~cm}$ above mean water level (Sasser 1977). Marsh vegetation recolonized bare soil within this range by the end of the first growing season following backfilling. Canals backfilled in winter, spring, or early summer were revegetated by September. Canals backfilled in the fall took approximately one year to be recolonized. No planting or seeding was performed. Species that recolonized varied with marsh type. Spartina alterniflora and $S$. patens predominated in salt and brackish marshes. Species in fresh and intermediate marshes varied, but typically Phragmites communis or Sagittaria lancifolia were dominant recolonizers. 


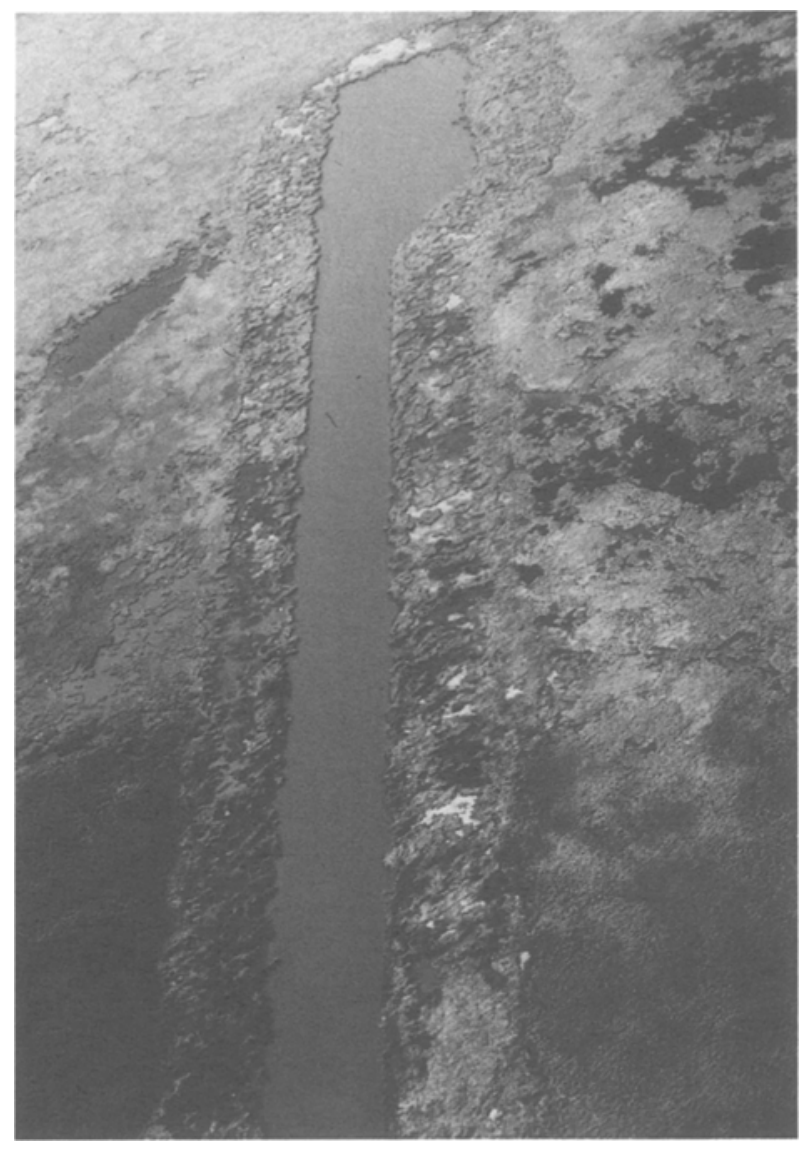

Figure 4. No emergent marsh was established in the Buckskin Bayou backfilled canal despite the use of most available spoil material as fill.

On the basis of these results, it is reasonable to expect that after five years backfilling will generally restore no more than $10 \%$ of the marsh cover in an average canal, or no more than $50 \%$ cover in exceptional cases. We do not know whether the area of marsh reestablished in the canal will increase or decrease over a longer period of time.

Marsh vegetation on spoil banks. Backfilling was much more effective at reestablishing emergent marsh vegetation on the regraded spoil banks than in the canal. Fifty \% or more of the area of the regraded spoil bank was revegetated by marsh at 17 out of 31 sites. The remaining areas of the spoil banks were improperly regraded and remained as elevated spoil deposits, or were dug too deep and were converted to open water. Emergent marsh was reestablished on more than $75 \%$ of the regraded spoil bank area at six sites and more than $90 \%$ at only two sites. This indicates that backfilling was only partially effective in converting regraded spoil banks to marsh. In eight

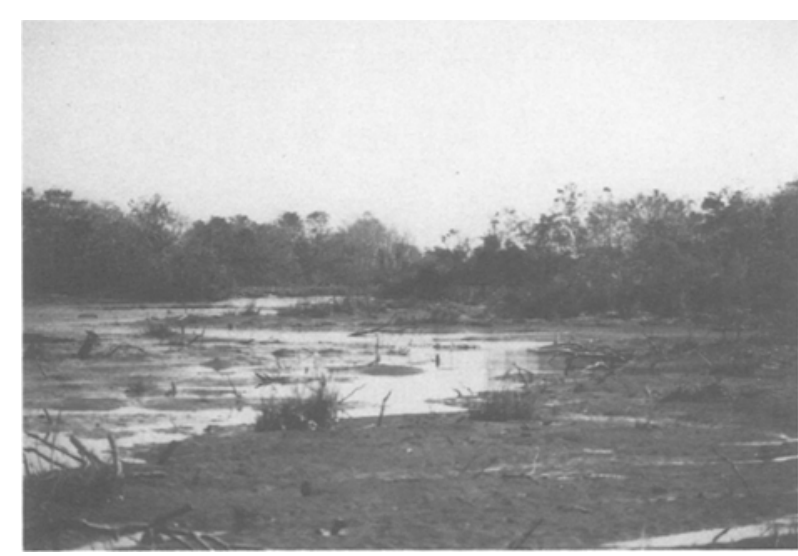

Figure 5. The spoil banks of the Boston Bayou backfilled canal were poorly backfilled, resulting in large areas of unvegetated mud and leaving large areas of spoil vegetation, including large trees.

cases, marsh was reestablished on less than $20 \%$ of the regraded spoil banks.

Spoil bank areas not supporting marsh vegetation after backfilling were covered by either spoil vegetation, open water, or unvegetated mud. The failure to restore marsh on the spoil banks was primarily a result of the poor operation of the backfilling dredge. Spoil vegetation remained when spoil banks were incompletely returned to the canal during backfilling (Figure 5). In some cases, spoil was left along the outer edge of the spoil bank beyond the reach of the dredge. Conversely, if the spoil bank was scraped too deeply, a portion of the spoil bank was converted to shallow open water or bare mud. The problem of conversion of the spoil banks to open water was most pronounced in six cases where open water covered more than $40 \%$ of the spoil bank area.

Restoration of soils. Regrading canal spoil banks partially restored spoil bank soil properties to predredging marsh conditions. Soil water content recovered more than the organic matter content. Water content of spoil bank soils was restored to resemble that of marsh soil at $22 \%$ of the canals sampled and partially restored at another 50\% (Table 4). Organic matter content remained no different than unfilled spoil bank soils at more than half $(62 \%)$ of the canals.

These marsh soils dry when deposited in spoil banks and organic matter oxidizes, leaving soil predominantly composed of mineral material. Lowering soil bank elevation by regrading probably accounted for the observed increase in soil water content. Further increases in water content to that similar to undisturbed marsh will probably require an increase in soil organic matter content and moisture holding capacity. 
Table 4. Restoration of backfilled spoil bank soils.

\begin{tabular}{lcc}
\hline & \multicolumn{2}{c}{$\%$ of all canals examined } \\
\cline { 2 - 3 } & Water content & Organic matter \\
\hline No restoration & 28 & 62 \\
Partial restoration & 50 & 28 \\
Complete restoration & 22 & 11 \\
\hline
\end{tabular}

Recovery of soil organic matter also depends on the reestablishment of vegetation, deposition of organic matter, and incorporation of organic matter into the soil structure. The time needed for complete recovery of marsh soil organic matter is not known but is apparently longer than five years.

\section{Factors Affecting Backfilling Success}

Marsh type. Backfilled canal depth was significantly lower in intermediate marshes than in brackish or fresh marshes. Insufficient data on canals in salt marshes made it difficult to compare them with the other marsh types. We were not able to predict backfilling success on the basis of marsh type, probably because of the great variation of vegetation within each marsh type. The reason for the poorer backfilling success in intermediate marshes is not clear. There were no obvious relationships between intermediate marsh type and other factors such as operator performance, canal size, location, or age. The average percentage of cover of marsh restored in the canal was lowest in intermediate marshes $(1.2 \pm 0)$ and highest in fresh $(9.2$ \pm 3.8 ) and salt marshes $(8.9 \pm 0)$ (Table 5). The average percentage of cover of marsh reestablished on the regraded spoil banks was highest in intermediate marshes $(68.6 \pm 0)$ and lowest in fresh marshes (34.7 $\pm 6.5)$ and salt marshes $(33.9 \pm 0)$.

The percentage of the area of the regraded spoil banks covered by spoil was lowest in fresh marshes $(16.9 \pm 5.9)$ and intermediate marshes $(24.6 \pm 0)$. The average percentage of cover of spoil on regraded spoil banks in brackish marshes and salt marshes was higher $(30.7 \pm 3.5$ and $35.4 \pm 0$, respectively). The low amount of spoil area partially accounts for the high success of marsh restoration on regraded spoil banks of canals in intermediate marshes. Another factor was the very low average percentage of cover of open water $(6.8 \pm 0)$. Fresh marshes had the highest average cover of open water $(48.4 \pm 5.6)$ and therefore had a lower average success of overall marsh reestablishment. The high amount of spoil returned in fresh marshes was at least partially responsible for the high percentage of open water on the spoil banks.

How well backfilling worked in different marsh types depended on the measure of success. Intermediate marshes were high in the total amount of marsh restored on the spoil banks but low on the amount of marsh restored in the canal and in the amount of canal backfilled. Fresh marsh canals were shallow, had high marsh restoration in the canal, but low marsh restoration on the regraded spoil banks. Brackish and salt marshes tended to fall into the middle, having fairly shallow depths and moderate amounts of marsh in the canal and on the backfilled spoil banks.

Success at any one canal could differ as a result of a number of factors besides marsh type. There was a wide range of values of success in all marsh types. In some cases there were statistically significant differences between categories (e.g., percentage of cover of marsh reestablished in the canal) because a large percentage of the entire population of backfilled canals was sampled. Small differences, though significant, do not necessarily indicate functional differences between categories.

Hydrologic unit. We hypothesized that backfilling success would differ between hydrologic units because of differences in sediment thickness, age, composition, or sediment deposition pattern that occur in deltaic distributary hydrologic units.

Coastal Louisiana is composed of two depositionary environments: the eastern Mississippi River Deltaic Plain, consisting of land formed by direct deposition of river-borne sediments, and the western Chenier Plain, formed by deposition of reworked deltaic sediments. The Chenier Plain sediments typically contain more mineral material and show lower rates of compaction and land subsidence.

We suspected that canals in the Chenier Plain would show better backfilling because lower subsidence and more mineral soils would result in more spoil material available for fill. Within the Deltaic Plain, we hypothesized that canals in more recently deposited hydrologic units would be deeper as a result of high subsidence and sediment compaction. This hypothesis was supported by the data. Backfilling success did not differ between hydrologic units within the Deltaic Plain (Barataria, Terrebonne, and Vermilion), but average backfilled canal depth in all deltaic hydrologic units was significantly greater than in the Chenier Plain (Table 5).

The average percentage of cover of marsh vegetation in the canal was also greater in the Chenier Plain $(12.4 \pm 0)$ than in the most successful Deltaic Plain hydrologic unit $(3.6 \pm 3.6)$. One possible reason for the success of backfilling in the Chenier Plain was a difference in operator performance. The amount of spoil returned in the Chenier Plain was high $195.5 \% \pm$ 
Table 5. Factors influencing canals restoration (mean values \pm 2 S.E.).

\begin{tabular}{|c|c|c|c|c|c|c|c|}
\hline & $\begin{array}{c}\text { Canal } \\
\text { depth } \\
\text { (meters) }^{\mathrm{a}}\end{array}$ & $\begin{array}{l}\text { \% Cover } \\
\text { of marsh in } \\
\text { backfilled } \\
\text { canal }\end{array}$ & $\begin{array}{l}\% \text { Cover } \\
\text { of marsh on } \\
\text { regraded } \\
\text { spoil banks }\end{array}$ & $\begin{array}{l}\% \text { Cover } \\
\text { of spoil on } \\
\text { regraded } \\
\text { spoil banks }\end{array}$ & $\begin{array}{c}\% \text { Cover } \\
\text { of open water } \\
\text { on regraded } \\
\text { spoil banks }\end{array}$ & $\begin{array}{l}\% \text { Spoil } \\
\text { returned }\end{array}$ & $\begin{array}{c}\% \\
\text { Soil organic } \\
\text { matter }\end{array}$ \\
\hline \multicolumn{8}{|l|}{ Marsh type } \\
\hline Fresh & $0.9 \pm 0.3$ & $9.2 \pm 3.8$ & $34.7 \pm 6.5$ & $16.9 \pm 5.9$ & $48.4 \pm 5.6$ & $95.7 \pm 0$ & $63.9 \pm 0$ \\
\hline Intermediate & $1.5 \pm 0.1$ & $1.2 \pm 0$ & $68.6 \pm 0$ & $24.6 \pm 0$ & $6.8 \pm 0$ & $85.6 \pm 0$ & $56.8 \pm 6$ \\
\hline Brackish & $0.9 \pm 0.1$ & $5.0 \pm 1.3$ & $41.9 \pm 3.3$ & $30.7 \pm 3.5$ & $27.4 \pm 3.3$ & $84.2 \pm 2.2$ & $35.9 \pm 3.3$ \\
\hline Salt & $1.0 \pm 0.9$ & $8.9 \pm 0$ & $33.9 \pm 0$ & $35.4 \pm 0$ & $26.8 \pm 0$ & $88.0 \pm 9.2$ & $20.4 \pm 0$ \\
\hline \multicolumn{8}{|l|}{ Hydrologic unit } \\
\hline Barataria & $1.3 \pm 0.1$ & $3.6 \pm 3.6$ & $26.4 \pm 18.0$ & $61.6 \pm 27.6$ & $11.9 \pm 9.5$ & $81.5 \pm 11.3$ & $66.7 \pm 8.6$ \\
\hline Terrebonne & $1.3 \pm 0.2$ & $0.0 \pm 0$ & $47.4 \pm 0$ & $33.4 \pm 0$ & $19.2 \pm 0$ & $88.9 \pm 2.0$ & $39.3 \pm 0$ \\
\hline Vermilion & $1.1 \pm 0.1$ & $2.7 \pm 0$ & $47.0 \pm 0$ & $27.6 \pm 0$ & $25.4 \pm 0$ & $79.3 \pm 0$ & $42.2 \pm 3.8$ \\
\hline Chenier Plain & $0.6 \pm 0.2$ & $12.4 \pm 0$ & $50.8 \pm 0$ & $12.7 \pm 0$ & $36.5 \pm 0$ & $95.5 \pm 0$ & $43.7 \pm 5.2$ \\
\hline \multicolumn{8}{|l|}{ Plug } \\
\hline Unnplugged & $1.0 \pm 0.1$ & $0.7 \pm 0$ & $35.8 \pm 0$ & $41.1 \pm 0$ & $23.1 \pm 0$ & $73.4 \pm 0$ & - \\
\hline Semi-plugged & $1.1 \pm 0.2$ & $4.8 \pm 1.9$ & $53.1 \pm 5.1$ & $31.9 \pm 6.4$ & $15.0 \pm 3.0$ & $87.3 \pm 0$ & - \\
\hline Plugged & $1.0 \pm 0.2$ & $8.6 \pm 1.8$ & $49.0 \pm 4.7$ & $15.2 \pm 3.1$ & $35.8 \pm 4.6$ & $96.8 \pm 0.6$ & - \\
\hline \multicolumn{8}{|l|}{ Permit } \\
\hline On-site & $0.9 \pm 0.2$ & $6.8 \pm 2.0$ & $51.9 \pm 5.4$ & $18.9 \pm 4.2$ & $29.3 \pm 5.0$ & $95.6 \pm 0.8$ & - \\
\hline Off-site & $1.1 \pm 0.1$ & $4.1 \pm 0$ & $39.9 \pm 0$ & $35.4 \pm 0$ & $24.7 \pm 0$ & $79.0 \pm 0$ & - \\
\hline
\end{tabular}

${ }^{\text {a }}$ One canal (Dupre Cut) was eliminated from calculations of depth because it was filled using spoil from an adjacent larger canal.

$0)$. The percentage of area of regraded spoil banks remaining covered by spoil vegetation was lower in the Chenier Plain $(12.7 \pm 0)$ than in deltaic hydrologic units (lowest was $27.6 \pm 0$ ). Superior backfilling success in the Chenier Plain may also have been a result of higher marsh elevations, lower subsidence rates, decreased erosion caused by tidal exchange, lower sediment depth, or other factors not measured in this study.

Time between dredging and backfilling. When dredged spoil is deposited on the marsh in spoil banks, it dries and the organic matter in the spoil oxidizes. Most of the loss of organic matter occurs within the first year of dredging (Monte 1978), probably because of the subsidence and shrinkage of spoil material (Okey 1918, Turner and Neill 1984). Spoil shrinkage has been cited as a reason why backfilling would never be successful (Matthews 1983). Although soils do shrink, it is apparent from this study that significant amounts of spoil remain for backfilling.

Since spoil bank age affects the volume of material available for backfilling, we hypothesized that the time between canal dredging and backfilling was related to backfilling success. These results show that there was a wide variation in the amount of backfilling especially in canals less than 120 months, or 10 years old (Figure 6). In canals backfilled more than ten years after dredging, there was an inverse relationship between final canal depth and time between dredging and backfilling. This indicated that while there was high

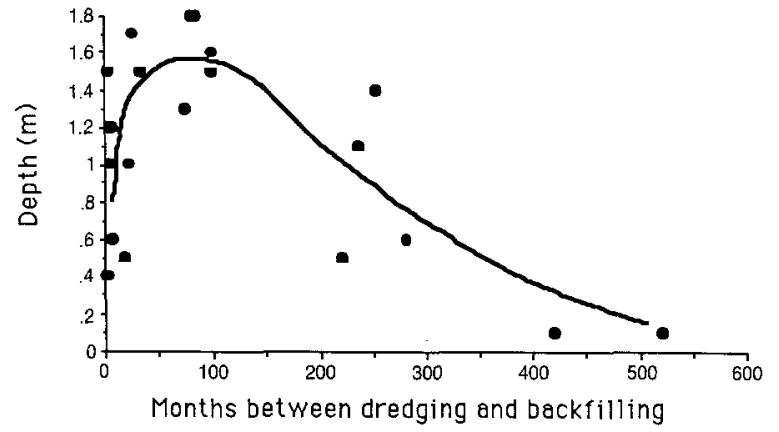

Figure 6. Plot of canal depth after backfilling against the number of years between dredging and backfilling. There is high variation in depth for canals backfilled less than ten years after dredging. Depth appears to increase with time between dredging and backfilling in canals backfilled more than ten years after dredging. The curve is drawn by hand.

variation in backfilling success in younger canals, backfilling success improved after ten years. This is an unexpected result if backfilling is assumed to be simply related to the amount of spoil available for backfilling. We suspect that backfilling success probably increased in older canals because the canals had partially filled in, so the canals were shallower before backfilling was performed. We do not have information on the depths of unfilled canals of different ages to test whether the depth of older canals was less than the approximate $2.4 \mathrm{~m}$ depth of newly dredged canals.

Canal size. Canal size (length, volume dredged, or 
area disturbed) showed no clear relationship to any measure of backfilling success.

Soil organic matter content. Soil organic matter content was another factor hypothesized to influence the amount of spoil material available for backfilling, and therefore success. Presumably, if other factors are equal, marsh soil organic matter content is directly related to spoil bank volume reduction. We are not, however, aware of any studies where this has been directly measured.

Soil organic matter content was inversely related to canal depth $(F=9.35, p<0.006)$. Canals in marshes with highly organic soils showed poorer backfilling success. Organic matter content was not related to the amount of marsh or open water on the spoil banks after backfilling. The percentage of marsh soil organic matter measured in this study showed high variability between sites and no clear trends between hydrologic units; thus soil organic matter cannot account for the better backfilling observed in this study in canals in the Chenier Plain. Soil organic matter generally decreased from fresh to salt marsh type.

Status of the plug. The status of the plug (present, absent, or deteriorated) at the mouth of backfilled canals was not related to backfilled canal depth. Plugged and semiplugged canals were, however, more likely to support a higher cover of emergent vegetation in the canal than unplugged canals. The need for a plug is often cited by landowners and permitting agencies as necessary to prevent spoil material from washing out of the canal after backfilling and to reduce erosion. Although plugs may help contain spoil material in the canal and reduce erosion (these parameters were not measured in this study), plugs did not have any effect on backfilled canal depth. Plugs slightly increased the amount of marsh in the canal, perhaps by reducing erosion.

The amount of marsh on regraded spoil banks was higher for plugged and semiplugged canals than for unplugged canals. Plugged canals had a higher amount of open water on the spoil banks than semiplugged or unplugged canals. It may be that by creating an impediment to drainage, plugs result in higher water levels and more open water on backfilled spoil banks. Partially plugged and plugged canals had similar amounts of marsh on the spoil banks, indicating that plugs may be effective in preventing erosion.

Plugs greatly increased the likelihood of establishing floating or submerged aquatic vegetation in the backfilled canal (Table 6). Aquatic vegetation was present in 12 out of 13 plugged backfilled canals where the presence of aquatic vegetation was surveyed. More than half ( 8 of 14) of the unplugged
Table 6. The influence of plugs on the presence of aquatic vegetation.

\begin{tabular}{lcc}
\hline Plug status & $\begin{array}{c}\text { No. canals with } \\
\text { aquatic vegetation }\end{array}$ & $\begin{array}{c}\text { No. of canals without } \\
\text { aquatic vegetation }\end{array}$ \\
\hline Plugged & 12 & 1 \\
Unplugged & 6 & 8 \\
\hline
\end{tabular}

canals examined were without aquatic vegetation. All plugged canals with vegetation contained large amounts of vegetation of several species. These results are consistent with other findings of higher frequency of occurrence of submerged aquatic vegetation in shallow ponds, lakes, and bayous behind weirs (Chabreck and Hoffpauir 1962, Chabreck 1968, Larrick and Chabreck 1976).

On- or off-site mitigation. Canals backfilled as onsite mitigation were slightly shallower and had higher cover of marsh on the spoil bank than canals backfilled off-site (Table 5). The reasons are unclear, but it may be related to the higher percentage of spoil material returned to canals backfilled on-site. We conclude that on-site mitigation works better than off-site restoration, but that the differences are not great enough to exclude one or the other in permitting decisions.

Dredge operator performance. Dredge operator skill was an important factor influencing how well the objectives of backfilling were met. Regrading spoil banks to the elevation of the surrounding marsh was crucial for marsh reestablishment. A skillful dredge operator could remove spoil banks very close to marsh level, provide maximum amount of spoil for canal fill, keep gouge scars and open water areas on the old spoil bank to a minimum, and increase marsh cover. If the dredge operator failed to return most of the spoil bank to the canal, spoil vegetation remained and the reestablishment of marsh was reduced. If the spoil bank was dug too deeply, the flooding tolerance of marsh plants often was exceeded and the regarded spoil bank remained unvegetated mud or open water. Although we observed a wide range in dredging quality at the 33 backfilled canals, there were enough cases of high-quality dredging to clearly demonstrate that the goal of leveling spoil banks to marsh elevation can be achieved using current bucket dredge techniques.

The amount of marsh reestablished on the backfilled spoil banks was significantly related to the percentage of spoil material returned to the canal $(F=$ $7.99, p<0.009)$. The more spoil material returned, the lower the elevation and the greater the cover of marsh reestablished. When too much spoil was returned, that tended to leave dredge gouge scars and 
areas of open water. Elevation appeared to be the key to plant reestablishment. This conclusion is similar to those of other studies that have shown that proper elevation is crucial to marsh plant establishment (Kadlec and Wentz 1974).

The area of open water on regraded spoil banks was not significantly related to the amount of spoil material returned. This probably occurred for two reasons. First, there was little difference in the percentage of spoil returned between spoil banks dug exactly to marsh elevation (in which case spoil banks were predominantly marsh) and spoil banks dug only several centimeters below marsh elevation (in which case spoil banks were predominantly open water). A small difference in spoil returned made a large difference in the amount of open water. Second, open water occurred on regraded spoil banks as a result of deep dredge gouge scars. Those scars were present even in some cases where a relatively small percentage of spoil was returned.

There was no clear relationship between the percentage of spoil material returned to the canal and final canal depth. The amount of spoil material available to be backfilled could also have been an important factor. The amount of available spoil material was not measured, but would presumably be related to a number of factors related to the rate or amount of organic matter oxidation, including canal age, marsh type, and marsh soil organic matter content. Backfilling success differed widely even among canals where the percentages of available spoil material that was backfilled were approximately equal. The average percentage of spoil returned to the canal was higher in fresh marshes $(95.7 \pm 0)$ than in intermediate $(85.6 \pm$ 0 ) and brackish marshes $(84.2 \pm 2.2)$, but there were no differences between other marsh types (Table 5). The mean percentage of spoil returned was greater for plugged canals $(96.8 \pm 0.6)$ than for semiplugged $(87.3 \pm 0)$ or unplugged canals $(73.4 \pm 0)$. For unknown reasons, operator performance, in terms of percentage of spoil returned, was better at canals backfilled on-site $(95.6 \pm 0.8)$ than at canals backfilled off-site $(79.0 \pm 0)$.

Other factors. From observations of the backfilled canals, it appeared that the amount of sediment available at a particular canal could have an influence on canal depth and backfilling success. No measure of sediment availability was made for each canal and no quantitative measures of the influence of sediment availability on backfilling success could be made.

We assumed that the differences in canal depth observed in the field were caused by either characteristics of the canal location (marsh type, hydrologic unit, soil organic matter) or the circumstances surrounding backfilling (e.g., percentage of spoil returned or spoil bank age). Because depth was not measured immediately after backfilling, it is possible that some differences in depth were related to variations in the time between backfilling and when depth was measured, as a result of natural filling or erosion. Depth was unrelated to amount of time elapsed since backfilling, indicating that there was no clear pattern of continued filling or erosion.

The oldest backfilled canal was backfilled in 1979, so there was no opportunity to monitor backfilled canals over a longer time period. Backfilled canals need to be monitored over longer time periods to determine if they will support increasing amounts of marsh vegetation, remain open water, or erode further into larger open water areas.

\section{Restoration of Natural Marsh Hydrology}

Much of the marsh loss occurring in Louisiana is the indirect effect of canal building rather than the direct conversion of marsh by canals, spoil banks, urban or agricultural expansion (Scaife and others 1983, Deegan and others 1984). Spoil banks play a major role in this indirect loss by disrupting marsh hydrology, creating unintentional impoundments, and blocking overland waterflow (Swenson and Turner in press). Removal of spoil banks has potential for restoring hydrology and eliminating some of the detrimental effects of canals. In the low-relief marsh environment, only slightly raised spoil banks could alter overland water flows. In most cases where less than $90 \%$ of the available spoil was backfilled, it is our opinion that the natural hydrology was probably still disrupted, although this is unquantified. There is no study on restoration of natural hydrology by backfilling.

\section{Backfilled Canals as Habitat for Fish and Wildlife}

In addition to reestablishing marsh vegetation, backfilling has great potential for improving unfilled canals as aquatic habitat for fish and wildlife. Backfilling creates shallow open water areas in the former canal that support large numbers of small fishes, including juveniles of species that use shallow marsh water bodies as nurseries (Neill and Turner 1987). Backfilled canals often bear a visual resemblance to natural marsh ponds, have similar dimensions, support aquatic vegetation, and have a high amount of marshwater edge (Figure 7). Such shallow marsh ponds have been widely shown to be excellent habitat for estuarine fishes and macroinvertebrates (Perry 1976, Weinstein 1979, Bozeman and Dean 1980). A 


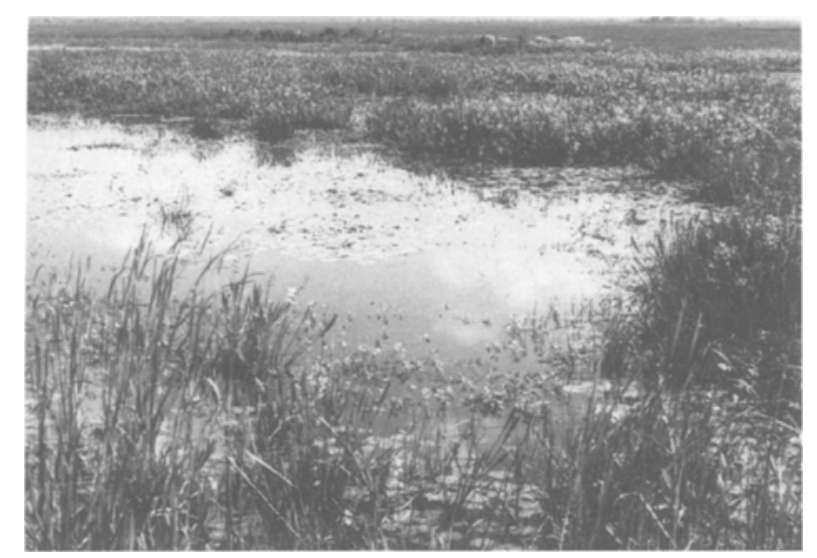

Figure 7. Marsh reestablishment and creation of shallow open-water habitat at the Mallard Bay West canal bear a physical resemblance to natural marsh ponds and have a high habitat value for fish and wildlife.

detailed comparison of these characteristics with unfilled canals and natural marshes has not been made and is recommended.

In a study comparing the benthic fauna in a backfilled canal to an unfilled canal and a natural bayou, Sikora and Sikora (1984) found that the mean annual abundance of macrofauna in the backfilled canal was similar to the natural creek and double the abundance in the unfilled canal. Mean annual abundance of meiofauna was six times greater in the backfilled canal than in the unfilled canal. The unfilled canal was classified as a highly disturbed benthic habitat, where the abundance of macro- and meiofauna appeared to be controlled by low levels of dissolved oxygen and high sulfide levels (Sikora and Sikora 1984). Populations in the backfilled canal appeared to be controlled by biotic factors, such as predation, and not by physical factors.

We conclude that vegetation restoration need not be complete for backfilling to result in effective benthic habitat creation and fish use. The presence of open water in the canal does not mean that habitat restoration was unsuccessful. In the canal studied by Sikora and Sikora, backfilling resulted in benthic habitat restoration even though little vegetation cover was reestablished in the canal.

Backfilling often results in the inadvertent creation of shallow open-water areas on the old spoil banks where the backfilling dredge scraped spoil too deeply. While this prevents reestablishment of emergent marsh vegetation, the shallow aquatic areas created may serve as valuable habitat in their own respect.

Backfilled canals also have the potential to be highquality habitat for waterfowl. Fifteen backfilled canals contained at least some species of aquatic vegetation known to be utilized by waterfowl as food, including widgeongrass (Ruppia maritima), dwarf spikerush (Eleocharis parvula), floating waterprimrose (Ludwigia peploides), coontail (Ceratophyllum demersum), southern naiad (Najas quadalupensis), fanwort (Cabomba caroliniana), and duckweed (Lemna minor). Shallow openwater areas in backfilled canals or on backfilled spoil banks are often less than $50 \mathrm{~cm}$ deep, a depth that can potentially be used by dabbling ducks for feeding (Chabreck 1979, Fredrickson and Drobney 1979).

Plugging canals encourages the growth of submerged aquatic vegetation, but restricts the access of migratory estuarine fishes (Neill and Turner 1987). We suggest that an improved strategy for managing backfilled canals for fish and wildlife is to plug canals to promote the growth of aquatic vegetation in fresh marshes or in preferred waterfowl areas, but leave canals in brackish and saline marshes open or semiplugged to allow access of juvenile migratory fishes.

This study briefly addressed the value of backfilled canals as fish and wildlife habitat. Comparisons of fish and wildlife use of backfilled canals, unfilled canals, and natural marsh ponds are rare, valuable, and recommended.

\section{Conclusions}

On the basis of our analysis of the factors affecting the success of backfilling, we make the following recommendations for the creation and management of backfilled canals:

- Restoration of marsh and shallow aquatic habitat will be more effective in the Chenier Plain than in the Deltaic Plain.

- Creation of shallow aquatic habitat will be more effective if backfilling is performed in marshes with low soil organic matter content.

- Backfilling is at least somewhat effective in all marsh types and for all sizes of canals.

- Backfilling success will be greater if canals selected for mitigation are less than 5 years old or greater than 20 years old.

- Canals should be monitored during backfilling to insure optimum dredge operator performance.

The mitigation of the environmental damages caused by canal construction has been slow to be accepted in a state for which oil and gas extraction provide a major source of state revenue and where, until recently, coastal marsh resources seemed limitless. That only 33 out of the thousands of existing abandoned canals have been backfilled poignantly illus- 
trates the neglect and lack of planning characterizing past coastal management in Louisiana.

Louisiana is experiencing alarming rates of coastal marsh loss and there is increased public pressure to plan future canal construction carefully. The best way to reduce the damages caused by new canals is not to dredge them in the first place. If that cannot be accomplished, backfilling offers a way to reduce their impacts. Perhaps more important, backfilling can be used to restore marsh at older, existing canals. But the issue of backfilling remains controversial, and few new dredging permits require backfilling. We have shown here that backfilling can effectively restore marsh on regraded spoil banks, create habitat for fish and wildlife, and be a useful management tool to alleviate coastal wetland loss. If backfilling is not used more in the future, then the barriers to implementation are probably going to be based more on political and social objections than on biological considerations.

\section{Acknowledgments}

This research was sponsored by the Coastal Energy Impact Program and the Coastal Management Division of the Louisiana Department of Natural Resources, and the National Marine Fisheries Service, through an Interagency Personnel Appointment to Erick Swenson, who assisted in the field effort. This manuscript was prepared with the support of the Louisiana Sea Grant Program, Louisiana State University. We thank the other coinvestigators in the project: R. Costanza, S. G. Leibowitz, K. L. McKee, I. A. Mendelssohn, J. P. Sikora, and W. B. Sikora.

\section{Literature Cited}

Adkins, G., and P. Bowman. 1976. A study of the fauna in dredged canals of coastal Louisiana. LA Department of Wildlife and Fisheries Technical Bulletin No. 18.72 pp.

Bahr, L. M., Jr., R. Costanza, J. W. Day, Jr., C. Neill, S. G. Leibowitz, and J. R. Fruci. 1983. Ecological characterization of the Mississippi Deltaic Plain Region: a narrative with management recommendations. US Fish and Wildlife Service, Division of Biological Services. FWS/OBS-82/69.

Bozeman, E. L., and J. M. Dean. 1980. The abundance of estuarine larval and juvenile fish in a South Carolina creek. Estuaries 3:89-97.

Chabreck, R. H. 1968. Weirs, plugs, and artificial potholes for the management of wildlife in coastal marshes. Pages 178-192 in J. D. Newsom (ed.), Proc. Marsh and Estuary Management Symposium, Division of Continuing Education, Louisiana State University, Baton Rouge, LA.

Chabreck, R. H. 1979. Winter habitat of dabbling ducksphysical, chemical and biological aspects. Pages 133-142 in
T. A. Bookhout (ed.), Waterfowl and wetlands-an integrated review. The Wildlife Society,

Chabreck, R. H., and C. M. Hoffpauir. 1962. The use of weirs in coastal marsh management in Louisiana. Proc. S.E. Game and Fish Comm. 16:103-112.

Chabreck, R. H., and G. Linscombe. 1978. Vegetative type map of the Louisiana coastal marshes. Louisiana Department of Wildlife and Fisheries, New Orleans.

Craig, N. J., R. E. Turner, and J. W. Day, Jr. 1979. Land loss in coastal Louisiana (USA). Environmental Management $3: 133-144$.

Davis, D. W. 1973. Louisiana canals and their influence on wetland development. Ph.D. diss., Louisiana State Univ., Baton Rouge. 199 pp.

Deegan, L. A., H. M. Kennedy, and C. Neill. 1984. Natural factors and human modifications contributing to marsh loss in Louisiana's Mississippi River deltaic plain. Environmental Management 8:519-528.

Fredrickson, L. H., and R. D. Drobney. 1979. Habitat utilization by postbreeding waterfowl. Pages 119-131 in T.A. Bookhout (ed.), Waterfowl and wetlands-an integrated review. The Wildlife Society,

Gagliano, S. M. 1973. Canals, dredging and land reclamation in the Louisiana coastal zone. Hydrologic and Geologic Studies of Coastal Louisiana, Report No. 14. Center for Wetland Resources, Louisiana State University, Baton Rouge, LA. 104 pp.

Gagliano, S. M., K. J. Meyer-Arendt, and K. M. Wicker. 1981. Land loss in the Mississippi River deltaic plain. Transactions Gulf Coast Association Geological Society 31:295-300.

Kadlec, J. A., and W. A. Wentz. 1974. State-of-the-art survey and evaluation of marsh plant reestablishment techniques: induced and natural. Contract Report D-74-9. US Army Engineers Waterways Experiment Station, Vicksburg, MI. 2 vols.

Larrick, W. D., Jr, and R. H. Chabreck. 1976. Effects of weirs on aquatic vegetation along the Louisiana coast. Proc. Ann. Conf. S.E. Assoc. Fish Wildl. Agencies 30:581-589.

Lindall, W. N., Jr., A. Mager, Jr., G. W. Thayer, and D. R. Ekberg. 1979. Estuarine habitat mitigation planning in the southeast. Pages 129-135 in G. A. Swanson (ed.), The mitigation symposium: a national workshop on mitigation losses of fish and wildlife habitat. General Technical Report R.-65, Rocky Mountain Forest and Range Exp. Sta., Forest Service, USDSA, Ft. Collins, CO.

Longley, W. L., R. Jackson, and B. Snyder. 1978. Managing oil and gas activities in coastal marshes. US Fish and Wildlife Service, Office of Biological Services, FWS/OBS-78/54.

Matthews, D. 1983. Checking up on Louisiana's wetlands. Exxon USA 22:12-15.

Mendelssohn, I. A., W. B. Sikora, K. L. McKee, and J. P. Sikora. 1984. An evaluation of backfilling canals as a means of mitigating the environmental impact of canals in south Louisiana: vegetation and benthos. Interim Report (phase II) to the Coastal Zone Management Section of the Louisiana Department of Natural Resources, Baton Rouge.

Monte, J. 1978. Impact of petroleum dredging on Louisiana's coastal landscape: a plant biogeographical analysis and resource assessment of spoil bank habitats in the Bayou La- 
fourche Delta. Ph.D. diss., Louisiana State Univ., Baton Rouge. $334 \mathrm{pp}$

Neill, C., and R. E. Turner. 1987. Comparisons of fish communities in open and plugged backfilled canals in Louisiana coastal marshes. North American Journal of Fisheries Management, 7(1):57-62.

Okey, C. W. 1918. The subsidence of muck and peat soils in southern Louisiana and Florida. Transactions of the American Society of Civil Engineers 82:396-422.

Perry, G. W. 1976. Standing crops of fishes of an estuarine area in southwest Louisiana. Proc. 30th Annual Southeasterm Fish and Wildlife Agencies 30:71-81.

Quammen, M. L. 1986. Measuring the success of wetlands mitigation. National Wetlands Newletter 8(5):6-8.

Sasser, C. S. 1977. Distribution of vegetation in Louisiana coastal marshes as response to tidal flooding. M.S. thesis, Louisiana State University, Baton Rouge. 40 pp.

Scaife, W. W., R. E. Turner, and R. Costanza. 1983. Coastal Louisiana recent land loss and canal impacts. Environment Management 7:433-442.

Sikora, W. B., and J. P. Sikora. 1984. Benthos. In R. E. Turner, I. A. Mendelssohn, R. Costanza, K. L. McKee, C. Neill, J. P. Sikora, W. B. Sikora, and E. Swenson, Evaluation of backfilling canals as a means of mitigating the environmental impact of canals. Final Report. Coastal Management Section, Louisiana Department Natural Resources.

Snedecor, G. W., and W. G. Cochran. 1967. Statistical methods, 6th ed. Iowa State Univ. Press, Ames. 593 pp.

Swenson, E. 1983. Marsh hydrological studies 1982-1983 data report. Coastal Ecology and Fisheries Institute, Center for Wetland Resources, Louisiana State University, Baton Rouge. LSU-CEFI-83-18.

Swenson, E. M., and R. E. Turner. In press. Spoil banks: effects on a coastal marsh water level regime. Estuarine, Coastal and Shelf Science.

Turner, R. E. 1985. Relationships between coastal land losses and canals and canal levees in Louisiana and management options. Biological Services Program, US Fish and Wildlife Service, Washington, DC. FWS/OBS-85. 71 pp.

Turner, R. E., K. L. McKee, W. B. Sikora, J. P. Sikora, I. A. Mendelssohn, E. Swenson, C. Neill, S. G. Leibowitz, and F. Pedrazini. 1983. The impact and mitigation of man-made canals in coastal Louisiana. Water, Science, and Technology $16: 497-504$.

Turner, R. E., and C. Neill. 1984. Revisiting impounded wetlands after 70 years. Pages 309-321 in R. J. Varnell (ed.), Water quality and wetland management conference proceedings. New Orleans, LA, August 4-5, 1983.

Weinstein, M. P. 1979. Shallow marsh habitats as primary nurseries for fish and shellfish, Cape Fear River, North Carolina. Fisheries Bulletin 77:339-357.

Wicker, K. M. 1981. Chenier Plain region ecological characterization: a habitat mapping study. User's guide to the habitat maps. Louisiana Dept. Natural Resources, Baton Rouge, LA. 55 pp. + appendices.

Wicker, K. M., and others. 1980. Mississippi Deltaic Plain region ecological characterization: a habitat mapping study. User's guide to the habitat maps. US Fish and Wildlife Service, Office Biological Services. FWS/OBS-78-07. 